\title{
Impact of Organic and Inorganic Fertilizers on Morphological and Biochemical Components of Arachis hypogaea L.
}

\author{
T. Azhaguthasan*, T. Ravimycin $* \dagger$ and K. Santhi** \\ *Department of Botany, Annamalai University, Annamalai Nagar, Chidambaram-608 002, Tamil Nadu, India \\ **Thiruvannamalai Arts and Science College, Thiruvannamalai, Tamil Nadu, India \\ $\dagger$ Corresponding author: T. Ravimycin; drmycin@gmail.com
}

Nat. Env. \& Poll. Tech.

Website: www.neptjournal.com

Received: 29-12-2020

Revised: 26-02-2021

Accepted: 26-04-2021

Key Words:

Biochemical constituents

Fertilizers

Growth

Arachis hypogaea L.

\begin{abstract}
The present investigation aims to study the comparative effect of different treatments of organic and inorganic fertilizers on the growth and biochemical constituents of groundnut (Arachis hypogaea L.). The plants were raised in the field with different treatments of fertilizers like arbuscular mycorrhizal fungi (AMF), Azospirillum (AZM), market waste compost (MWC), nitrogen (N), phosphorus (P) and potassium $(K)$. The plant samples were collected after 15, 30, 60 and 90 days for the measurement of different growth parameters. The analysis of the morphological and biochemical parameters such as shoot and root length, fresh and dry weight, total leaf area, chlorophyll ' $a$ ' and 'b', total chlorophyll, amino acids, starch and total sugar was made at different days intervals. The effect of organic and inorganic fertilizers on growth parameters and biochemical constituents of leaves was significantly increased in all the treatments. In general, bio-fertilizer applications are to boost the effectiveness of Arbuscular Mycorrhizal Fungi (AMF), Azospirillum (AZM) and market waste compost (MWC) on nodulation and yield of groundnut. The organic fertilizers treated plants showed better performance than the inorganic fertilizers and control.
\end{abstract}

\section{INTRODUCTION}

Groundnut (Arachis hypogaea L.) is a leguminous plant and used for human consumption all over the world. It is the most significant oil crop and requires a suitable amount of plant nutrients at the correct instant for healthier yield and quality (Thayamini 2018). Consequently, the utilization of element fertilizers has concerned the insubstantial environmental balance of the soil, polluted groundwater, developed resistant races of pathogens and increased human healthiness risks. Chemical pollutants are exceedingly dispersed in the atmosphere and cause severe harm to human health, soil as well as the atmosphere (Ignacimuthu et al. 2007).

The residual toxicities of chemical fertilizers pretense the problem of environmental pollution and reduction of essential nutrients due to random use of inorganic fertilizers which cause a severe hazard to the sustainability of crop invention. Intended for constant groundnut production, the present farming demand integrated use of organic and inorganic fertilizers beside the bio-fertilizers. Arbuscular mycorrhizal fungi (AMF) are among the most general soil fungi and the mass of plant species has associations with AMF species. Therefore, it becomes essential to explore the most effective combination of inorganic fertilizers and bio-fertilizers for sustaining soil fertility and producing quality products. The bio-fertilizers, besides providing a good substrate for crop growth, facilitate the propagation of beneficial microbes in soil and also provide a residual effect for ensuing crops. These inoculants aid in gathering nutrient demands of crops through proper nitrogen fixation by increasing nodulation and solubilization of insoluble phosphorus and extend the nutrient absorption to inaccessible zones. In the present investigation, the effect of bio-fertilizers and inorganic fertilizers on the growth and biochemical components of groundnut have been studied.

\section{MATERIALS AND METHODS}

\section{Experimental Site}

The study was conducted as a field experiment at Botanical Garden, Department of Botany, Annamalai University, Tamil Nadu, India.

\section{Cultivar}

The seeds of groundnut (Arachis hypogaea L.) var. VRI 2 were procured from the Regional Research Station of Tamil Nadu Agricultural University, Virudhachalam, Cuddalore District, Tamil Nadu, India.

\section{Methods}

The experiment was conducted in randomized block design with five replication treatments. The treatments were 
T1- Control, T2- Arbuscular Mycorrhizal Fungi (AMF), T3-Azospirillum (AZM), T4- Market waste compost (MWC), T5- AMF+AZM+MWC, T6- Nitrogen (N), T7- Phosphorus (P), T8- Potassium (K), and T9- $\mathrm{N}+\mathrm{P}+\mathrm{K}$. The garden soil and selected groundnut seeds were sown in the field irrigated with normal tap water and maintained as the control. Various growth and biochemical parameters were recorded after 15, 30, 60 and 90th days.

\section{Fertilizers}

The AM Fungi (Glomus fasciculatum) and Azospirillum were collected from the Department of Microbiology, Tamil Nadu Agricultural University (TNAU), Coimbatore, Tamil Nadu, India. Raw organic materials like vegetable wastage enhance their suitability for application to the soil as a fertilizer resource, after having undergone composting.

\section{Morphological and Biochemical Studies}

The morphological studies were carried on the shoot and root length, fresh and dry weight and total leaf area. The following methods were used for the estimation of chlorophyll (Sadasivam \& Manickam 1996), total free amino acids (Moore \& Stein 1948), Starch (Summer \& Somers 1949) and total sugar (Nelson 1944).

\section{Statistical Studies}

Statistical analysis of experimental results was carried out by SPSS version 16.0 (Two-way ANOVA). All the data were taken as a mean of five replications. The level of significance was calculated at $\mathrm{P} \leq 0.05 \%$.

\section{RESULTS AND DISCUSSION}

The effect of organic and inorganic fertilizers on the shoot and root length was observed and given in Figs. 1 and 2. Both the fertilizer treatments had shown a significant improvement on shoot and root length of groundnut. The highest shoot length was observed at (T5) treatment ( $68.3 \mathrm{~cm} /$ plant) followed by T9 $(65.8 \mathrm{~cm} /$ plant $)$ on the 90 th day. A similar trend was noticed in root length of the groundnut on all the sampling days. In general, the application of bio-fertilizers treatments improves plant growth. Improvement of plant growth was significantly found by the application of both organic and inorganic fertilizers as source of mineral nutrition. Mineralization process of the organic substances releases the nutrient elements which leads to plant growth. Bio-fertilizers release nutrients more slowly but store them longer in the soil (Ayoola \& Makinde et al. 2009). The nutrients from organic fertilizers support rapid root development (Baldi et al. 2010), which may have enhanced plant growth towards the end of plant life. Availability of organic substances, besides contrib- utes to crop growth and yield directly by supplying nutrients and indirectly by modifying soil physical properties such as stability of aggregates and porosity that can improve the root growth rhizosphere and stimulate plant growth (Goss et al. 2013). Plant growth is influenced by nitrogen, phosphorus and potassium. Nitrogen as a component of chlorophyll, division and enlargement of cells in the apical meristem, the activity of the apical meristem generates the shoot growth that affects the increase of plant height.

The effect of organic and inorganic fertilizers on the fresh and dry weight is presented in Figs. 3 and 4. All the treated plants showed a stimulatory effect on the fresh and dry weight of groundnut over control. The highest fresh weight was observed at combined treatments of organic compost T5 (66.88 g/ plant) followed by combined treatments of inorganic fertilizers T9 (54.76 g/plant). A similar trend was noticed in dry weight on the groundnut on all the interval days. Among the treatments, combined treatment was found to be more effective.

Under the application of both the fertilizers, the leaf area of the plant was increased with increasing treatment on all the sampling days. The leaf area was more in bio-fertilizer treatments as compared to inorganic fertilizer. The increased fresh and dry weights of plants could increase the chance for nutrient uptake throughout the highest exploitation of soil. Similar results found by Youssef et al. (2004) clearly indicate that the application of bio-fertilizers in Calendula officinallis and Matricaria recutita increased the plant growth and dry weight of shoot in the medicinal plants. The increase in leaf area could be due to the increase in the water content of the leaves and the presence of organic and inorganic nutrients.

The effect of bio-fertilizers and inorganic fertilizers treatments on parameters such as chlorophyll 'a' and 'b', total chlorophyll, total free amino acids, starch and total sugar content of leaves at different stages of the interval is represented in Figs. 6-11. Both the treatments had a significant effect on all the biochemical parameters and photosynthetic pigments when compared to the control plants. Chlorophyll 'a' was always higher than the chlorophyll ' $b$ ' in all the fertilizer treatments. Among the organic fertilizer treatments, the highest total chlorophyll content was observed in combined treatment T5 (2.04 mg/g fr.wt.) followed by T1, T2, T3 and $\mathrm{T} 4$ at 60 days. Moreover, fertilizers application, in addition, affects the accumulation of macro aggregate protected carbon and nitrogen. The application of only organic fertilizer, without the inorganic fertilizers, could not supply adequate nutrients that are responsible for chlorophyll synthesis. A high amount of total chlorophyll is necessary to sustain photosynthetic pigments and synthesize the enzymes resulting in increased growth and yield of groundnut plants (Ghosh et al. 2004). The addition of NPK nutrients can raise plant growth 


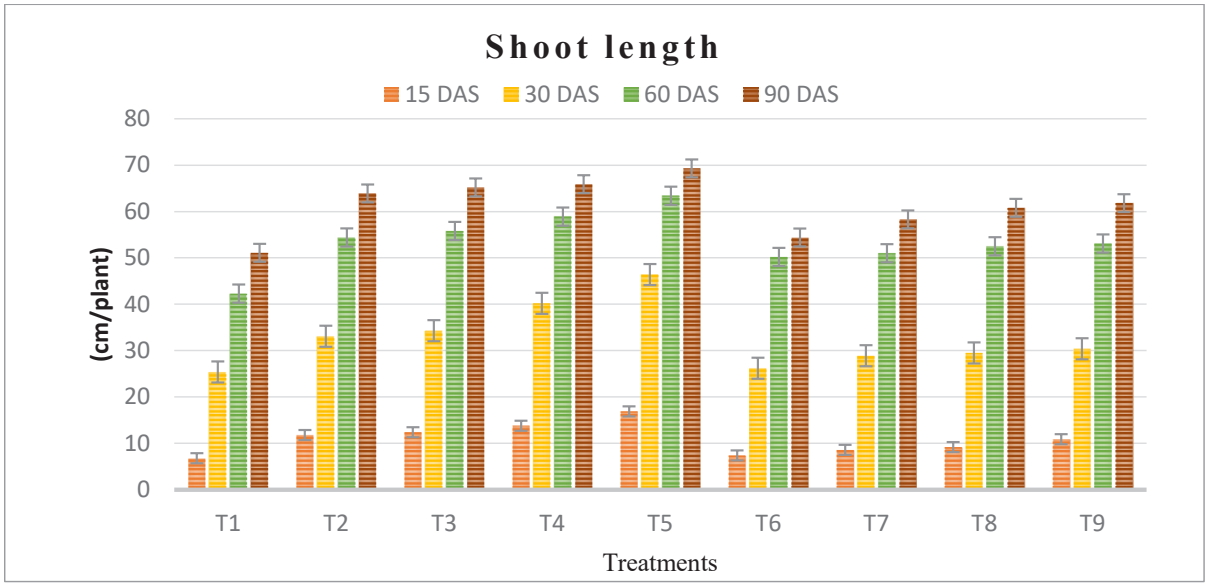

Fig. 1: The effect of organic and inorganic fertilizers on shoot length $(\mathrm{cm} / \mathrm{plant})$ of groundnut.

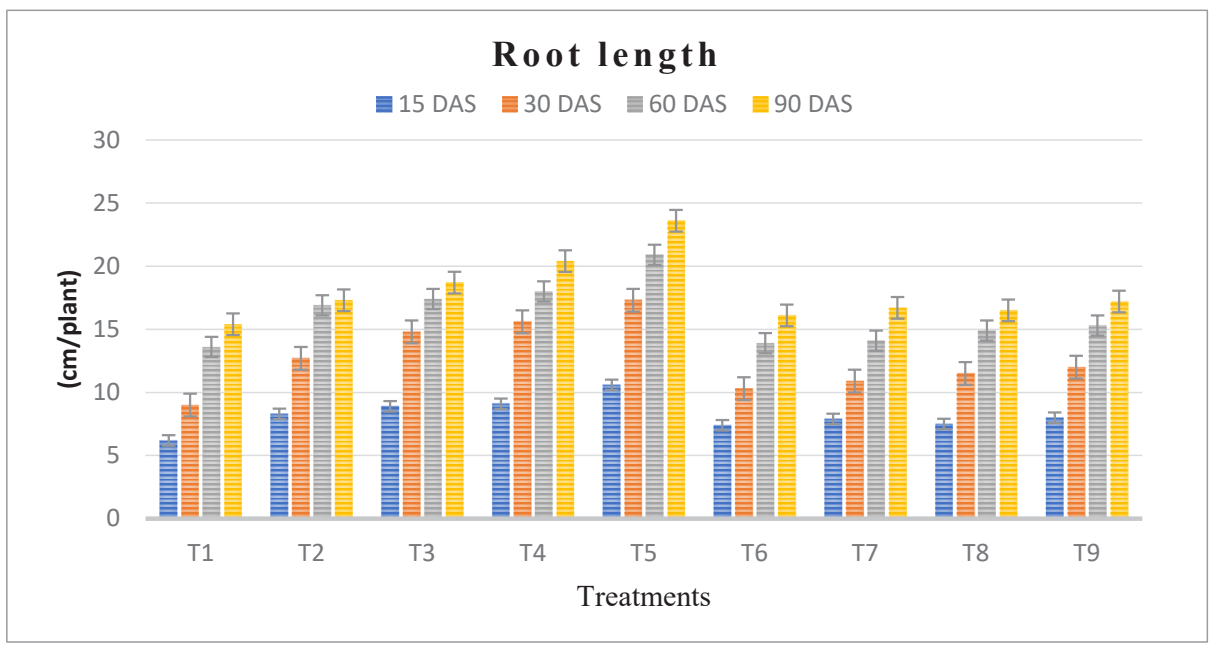

Fig. 2: The effect of organic and inorganic fertilizers on root length $(\mathrm{cm} / \mathrm{plant})$ of groundnut.

and production because these elements can stimulate roots, toughen plant stems and increase photosynthesis rates (Ayissa \& Kebebe 2011). Similar, results were found in maize and Sorghum plants (Amujoyegbe et al. 2007).

A significant difference in total free amino acid content was observed in both the treatments when compared to the control. Among the organic fertilizer treatments, the highest amino acid content was observed in combined treatment $\mathrm{T} 5$ ( $8.86 \mathrm{mg} / \mathrm{g}$ fr.wt.) followed by T1, T2, T3 and T4 on the 60th day. While, among the inorganic fertilizer treatment, the combined treatment $\mathrm{T} 9$ showed the highest value when compared to individual treatments. Amino acid is the monomer of protein, the regular preserved food material insincere by plant system. It may be ascribed to increased nitrogen uptake of leaves due to the combined inoculation of bio-fertilizers. Since, bio-fertilizers support phytohormones manufacturing, which stimulates nutrient absorption as well as photosynthesis process, as a result of this amino acids content increases (Naser et al. 2016). Similar findings of the increasing trend in amino acids due to fertilizer application were reported in Albizia lebbek (Kumudha \& Gomathinayagam 2007) and maize (Tejeda et al. 2008). In addition, amino acids may play an important role in plant metabolism and protein assimilation which is necessary for cell formation and consequently increase in fresh and dry matter (Nagwa et al. 2020).

The starch content in leaf of groundnut treated with organic and inorganic fertilizers also showed a significant difference. The highest starch content was observed in combined treatments on the 90th day. Among the organic fertilizer treatments, the highest sugar content was observed in combined treatment $\mathrm{T} 5(7.96 \mathrm{mg} / \mathrm{g}$ fr.wt.) followed by T1, T2, T3 and T4 on the 90th day. In both the treatments, 


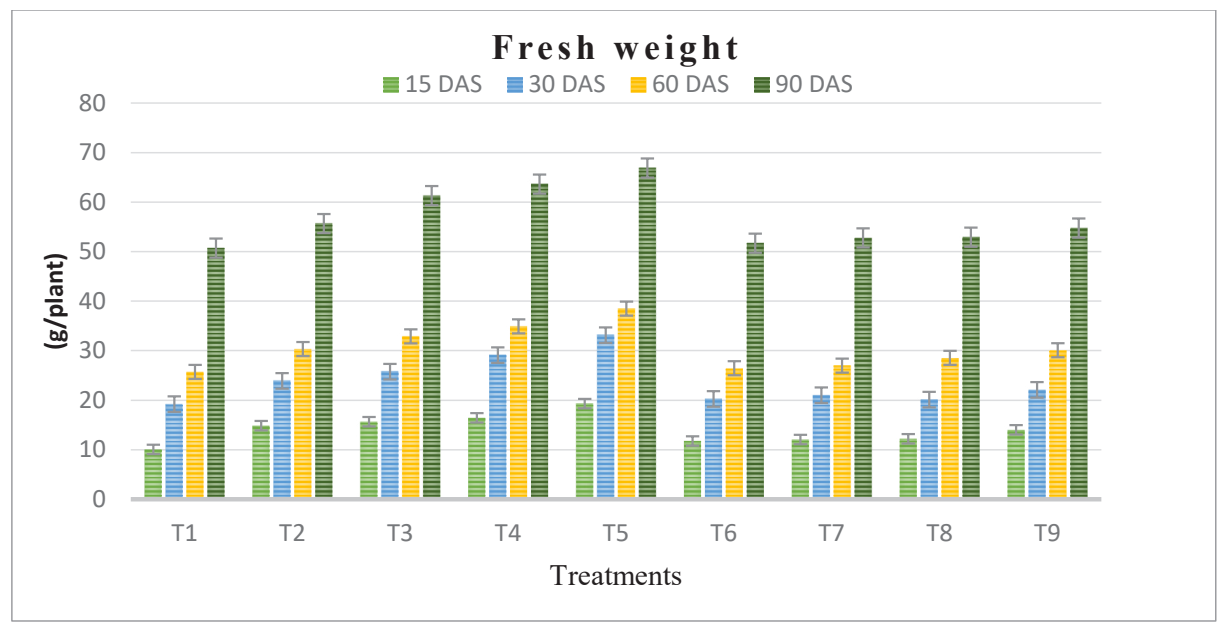

Fig. 3: The effect of organic and inorganic fertilizers on fresh weight (g/plant) of groundnut.

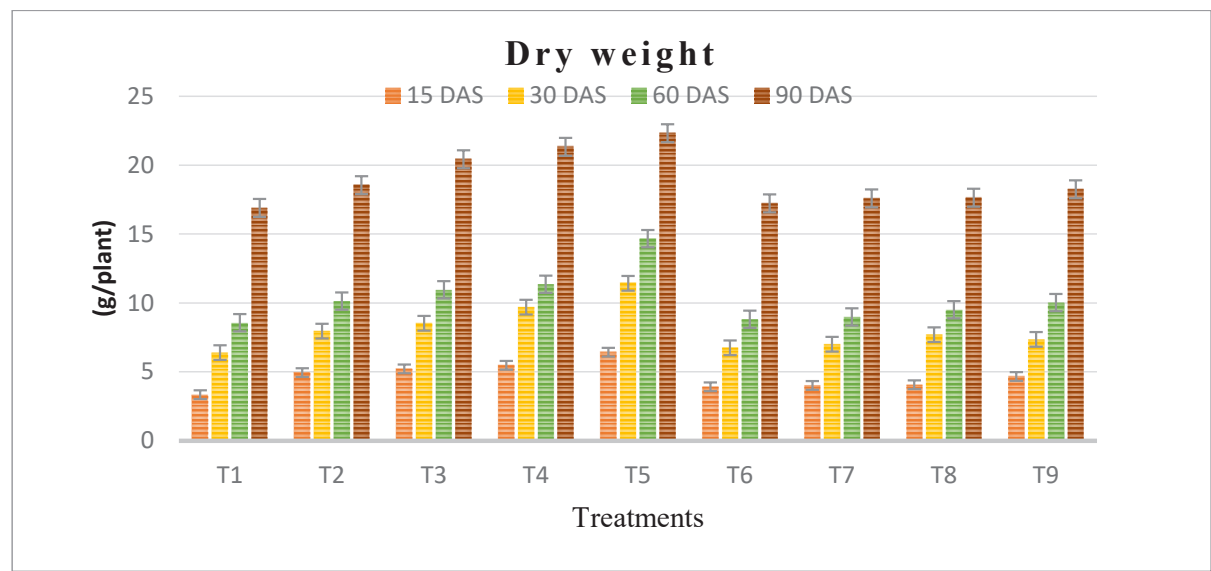

Fig. 4: The effect of organic and inorganic fertilizers on dry weight (g/plant) of groundnut.

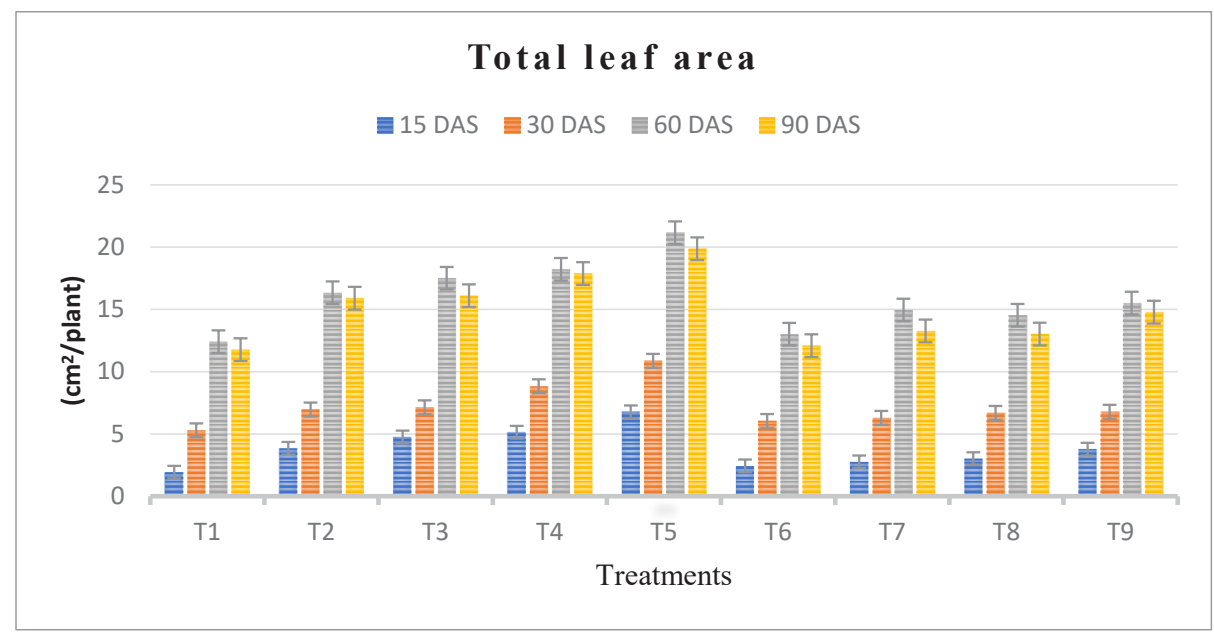

Fig. 5: The effect of organic and inorganic fertilizers on total leaf area (cm2/plant) of groundnut. 


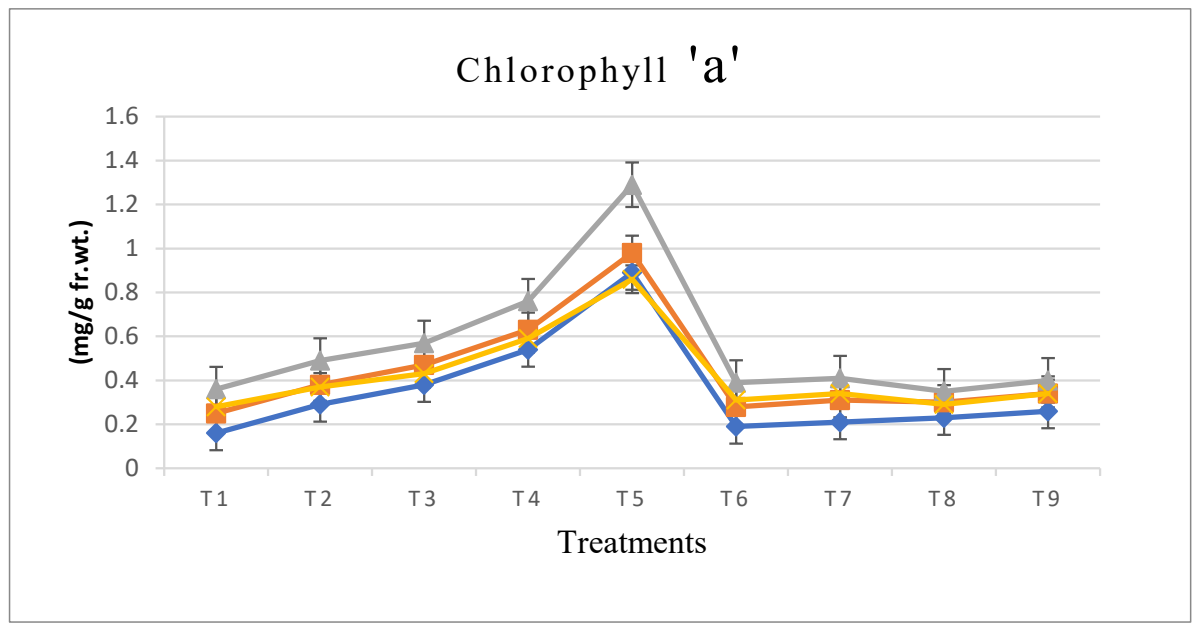

Fig. 6: The effect of organic and inorganic fertilizers on chlorophyll 'a' content (mg/g fr.wt.) of groundnut.

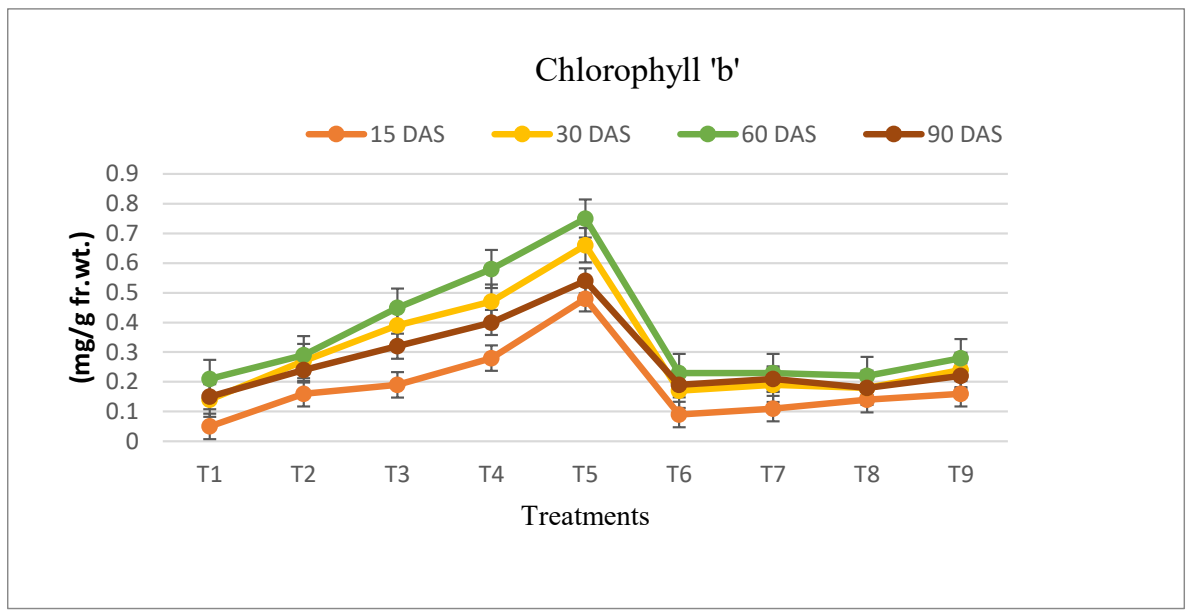

Fig. 7: The effect of organic and inorganic fertilizers on chlorophyll 'b' content (mg/g fr.wt.) of groundnut.

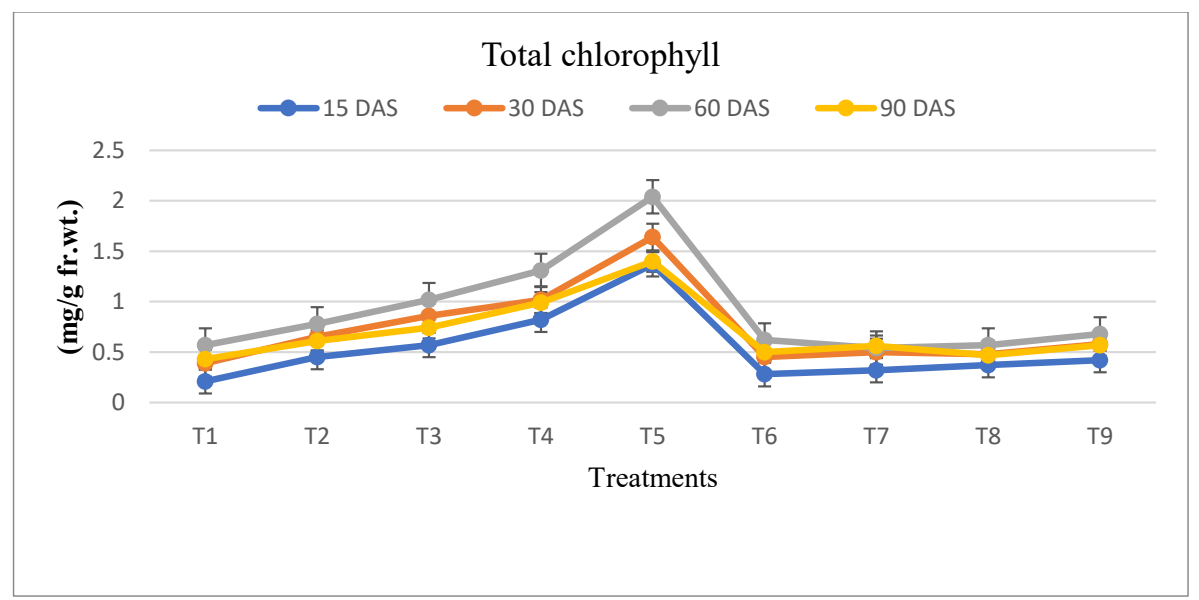

Fig. 8: The effect of organic and inorganic fertilizers on total chlorophyll contents (mg/g fr.wt.) of groundnut. 


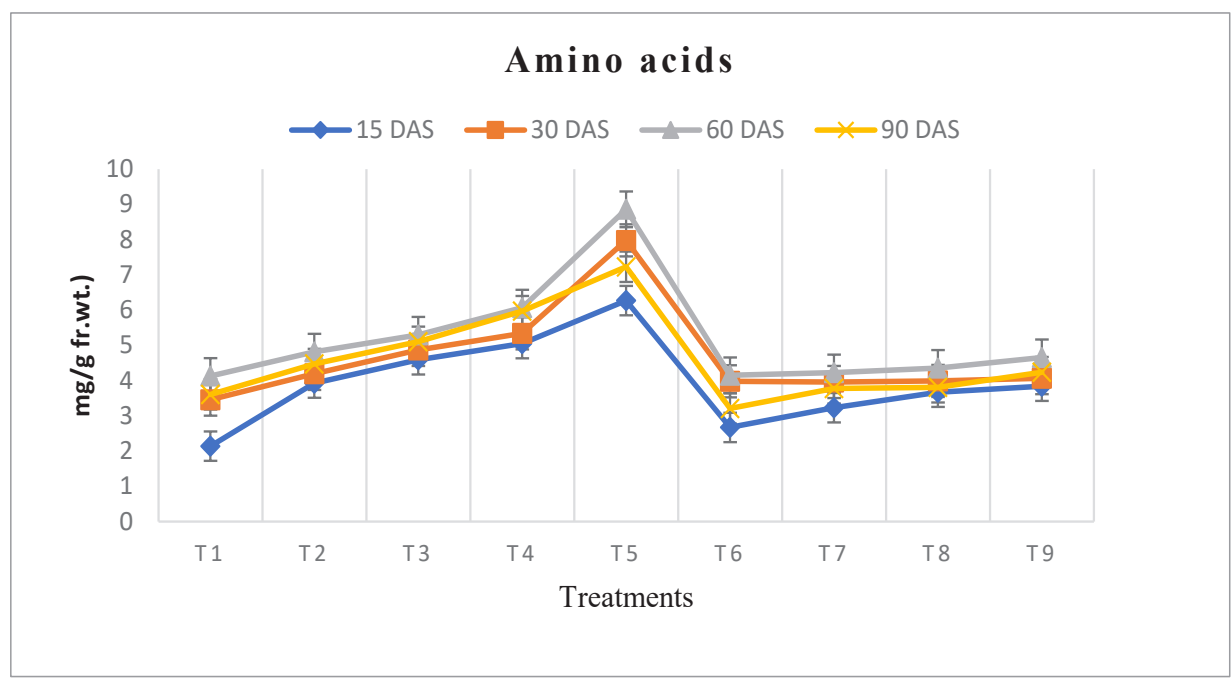

Fig. 9: The effect of organic and inorganic fertilizers on amino acid contents (mg/g fr.wt.) of groundnut.

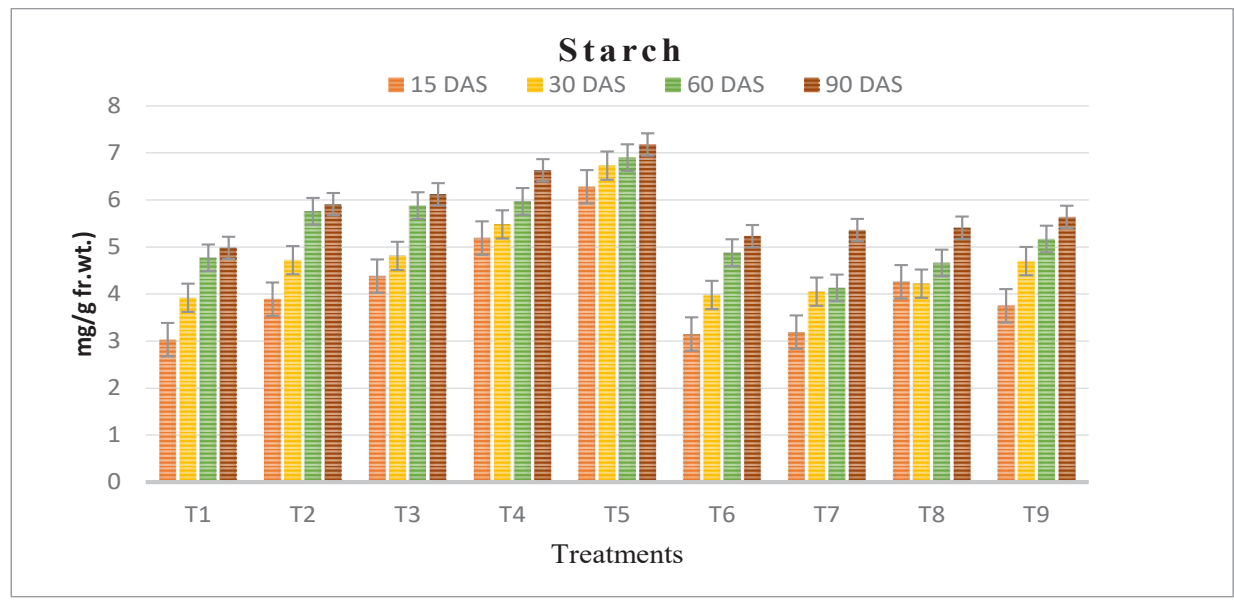

Fig. 10: The effect of organic and inorganic fertilizers on starch contents ( $\mathrm{mg} / \mathrm{g}$ fr.wt.) of groundnut.

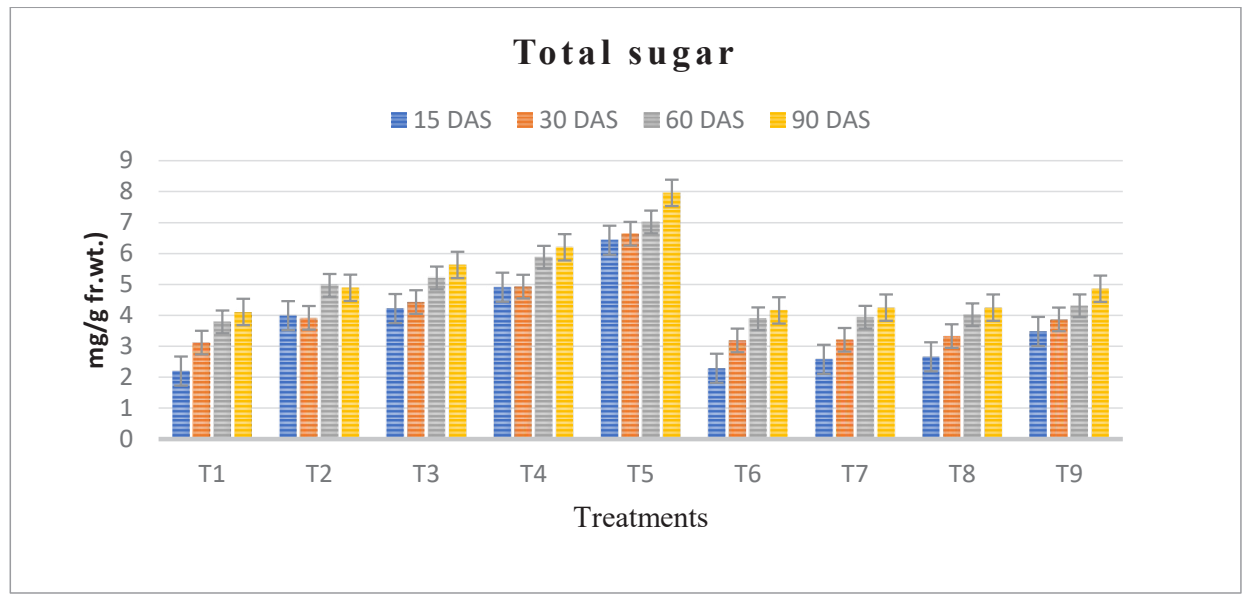

Fig. 11: The effect of organic and inorganic fertilizers on total sugar contents (mg/g fr.wt.) of groundnut. 
combined treatments reported the highest evaluation, even though organic fertilizer treatment is found to be more efficient in inducing total sugar content. Carbohydrates are important energy constituents that are required for all the living organisms. The plant manufactures its organic substances during photosynthesis and breaks during respiration. The sugar content increase was higher in bio-fertilizer applied plots. The accumulation of the carbohydrates content due to various fertilizer applications conformed with the previous studies in different species such as potato (Mahendran \& Kumar 1998), Pisum sativum (Nirmal et al. 2006) and Albizia lebbek (Kumudha \& Gomathinayagam 2007).

\section{SUMMARY AND CONCLUSION}

The effect of organic and inorganic fertilizers on growth parameters and biochemical constituents of leaves was significantly increased in all the treatments. In general, bio-fertilizer applications are to boost the effectiveness of Arbuscular Mycorrhizal Fungi, Azospirillum and market waste compost on nodulation and yield of groundnut. The organic fertilizers treated plants showed better performance than the inorganic fertilizers and control. For sustainable groundnut production, recent farming demands an integrated use of organic and inorganic fertilizers along with biofertilizers. Hence, further study on the long-term application of bio-fertilizers, low-cost inputs on soil fertility, and groundnut production would be recommended.

\section{ACKNOWLEDGMENT}

The authors are thankful to Professor Dr. K.C. Ravindran, Head of the Department and Dr. V.Venkatesalu, Professor and Director (DARE), Department of Botany, Annamalai University for valuable suggestions during the investigation.

\section{REFERENCES}

Amujoyegbe, B. J., Opabode, J. T. and Olayinka, A. 2007. Effect of organic and inorganic fertilizer on yield and chlorophyll content of maize (Zea mays L.) and sorghum Sorghum bicolour (L.) Moench). African Journal of Biotechnology, 6(18): 69-73.

Ayissa, T. and Kebebe, F. 2011. Effect of nitrogenous fertilizer on the growth and yield of cotton (Gossypium hirsutum L.) varieties in
Middle Awash, Ethiopia. Ethiopia Journal of the Drylands, 4: 248-258. Ayoola, O.T. and Makinde, E.A. 2009. Maize growth, yield and soil nutrient changes with $\mathrm{N}$-enriched organic fertilizers. African Journal of Food, Agriculture, Nutrition and Development, 9: 580-592.

Baldi, E., Toselli, M., Eiseenstat, D. M. and Marangoni, B. 2010. Organic fertilization leads to increased peach root production and lifespan. Tree Physiol., 30: 1373-82.

Ghosh, P. K., Ajay, Bandyopadhyay, K. K., Manna, M. C., Mandal, K. G., Misra, A. K. and Hati, K. M. 2004. Comparative effectiveness of cattle manure, poultry manure, phosphocompost and fertilizer-NPK on three cropping systems in vertisols of semi-arid tropics. I. Crop yields and system performance. Bioresource Technology, 95: 85-93.

Goss, M. J., Tubeileh, A. and Goorahoo, D. 2013. A review of the use of organic amendments and the risk to human health. Advances in Agronomy, 275-379.

Ignacimuthu, S. and Vendan, S.E. 2007. Botanical pesticides in insect pest management.Uttar Pradesh J. Zoo., 4(Suppl. 1): 141-154.

Kumudha, P. and Gomathinayagam, M. 2007. Studies on the effect of biofertilizers on germination of Albizia lebbek (L.) Benth. seeds. Adv. Plant Sci., 417-421.

Mahendran, P.P. and Kumar, N.I. 1998. Effect of biofertilizers and nitrogen on nutritional quality tuber yield and certain quality parameters of potato cv. Kufri Joti. South Indian Hort., 46: 97-98.

Moore, S. and Stein, W.H. 1948. Photometric method for use in the chromatography of amino acid. J. Bio. Chem., 176: 367-388.

Nagwa, M. K., Hassan, Neama, M., Marzouk, Zakaria, F. Fawzy and Said A. Saleh. 2020. Effect of bio-stimulants foliar applications on growth, yield, and product quality of two Cassava cultivars. Bulletin of the National Research Centre, 44:59.

Naser, H.M. et al. 2016. Effect of biofertilizers and putrescine amine on the physiological features and productivity of date palm (Phoenix dactylifera L.) grown on reclaimed-salinized soil. Trees, 30(4): $1149-1161$

Nelson, N. 1944. A photometric adaptation of the Somogyi's method for the determination of reducing sugar. Anal. Chem., 31: 426-428.

Nirmal, D., Kumar, A., Singh, R.K., Rai, A.K. and Rai, M. 2006. Effect of biofertilizers on quality of vegetable pea (Pisum sativum L.). Plant Arch., 6: 525-527.

Sadasivam, A. and Manickam, A. 1996. Biochemical Methods. New Age International Publishers, New Delhi, pp. 90-134.

Summer, J.B. and Somers, C.F. 1949. Laboratory Experiment in Biological Chemistry. 2nd New York: Academic Press, pp. 173.

Tejeda, M., Gonzalez, J.L., Garcia-Martinez, A.M. and Parrodo, J. 2008. Effects of different green manures on soil biological properties and maize yield. Bioresource Technol., 1758-1767.

Thayamini, H. Seran 2018. Effects of inorganic and organic nutrients combinedly used on yield and quality of groundnut (Arachis hypogaea L.), Bangladesh J. Sci. Ind. Res., 53(4): 289-296.

Youssef, A.A., Edri, A.E. and Gomma, A.M. 2004. A comparative study between some plant growth regulators and certain growth hormones producing microorganisms on growth and essential oil composition of Salvia officinalis L. Plant. Annl. Agric. Sci., 49: 299-31. 